\title{
DIDYMODON AUSTRALASIAE (POTTIACEAE, BRYOPHYTA), A NEW SPECIES FOR RUSSIA
}

\author{
DIDYMODON AUSTRALASIAE (POTTIACEAE, BRYOPHYTA), \\ НОВЫЙ ВИД ДЛЯ РОССИИ
}

\author{
Olga M. AfONInA ${ }^{1}$, IRINA V. CZERnYADJEVA ${ }^{1}$, ElENA A. IGNATOVA ${ }^{2} \&$ JAN KUČERA $^{3}$ \\ ОЛЬГА М. АФОНИНА ${ }^{1}$, ИРИНА В. ЧЕРНЯДЬЕВА ${ }^{1}$, ЕЛЕНА А. ИГНАТОВА $^{2}$, ЯН КУЧЕРА ${ }^{3}$
}

Abstract

Didymodon australasiae is reported for the first time from Russia. It was collected in the south of Zabaikalsky Territory, in Sokhondinsky Nature Reserve. This locality extends northward its known distribution in Eurasia. Description, illustrations and ecological data based on Siberian material are provided.

Резюме

\begin{abstract}
Didymodon australasiae впервые приводится для России. Он был собран на юге Забайкальского края, в Сохондинском заповеднике. Данное местонахождение является самым северным в Евразии. Приводится описание, иллюстрации и данные об экологии вида на основании образцов из Сибири.
\end{abstract}

KEYWORDS: mosses, Russia, Zabaikalsky Territory, moss flora, new record.

\section{INTRODUCTION}

The genus Didymodon is one of the largest and taxonomically most difficult in the family Pottiaceae. Zander (1993) accepted 122 species in his to-date latest comprehensive enumeration, but a modern revision of the whole genus has not yet been accomplished. In the "Checklist of mosses of East Europe and North Asia" (Ignatov et al., 2006), 21 species of Didymodon were listed for the territory of Russia. Since then, one species, D. zanderi Afonina \& Ignatova, was described as new for science (Afonina \& Ignatova, 2007), and five species were subsequently added to Russian moss flora as a result of extensive floristic investigation in different areas of the country (Afonina et al., 2010). The diversity of the genus in Zabaikalsky Territory turned out to be especially rich: it currently includes 17 species (unpublished data of the authors). This richness can be explained by the peculiarity of climate and landscape diversity of the region, which provides a great diversity of habitats suitable for the species of Didymodon. The territory is generally mountainous, and large areas in its southern and especially southeastern part are occupied by the steppe and foreststeppe vegetation.
In the course of identification of recent moss collections from Zabaikalsky Territory, Didymodon australasiae (Hook. \& Grev.) R.H. Zander was detected; it represents an additional novelty for the moss flora of Russia. The species was collected in Sokhondinsky Nature Reserve, which is situated in the south of Zabaikalsky Territory. Didymodon australasiae occurs at all continents in mostly xeric areas (Jiménez et al., 2005); the nearest known location of the species is in Mongolia (Tsegmed, 2010). Beside that, it is reported from southern Kazakhstan, Uzbekistan, Afghanistan and Turkmenistan (Abramov et al., 1986; Jiménez et al., 2005). Some of the earlier Asian records were published under the names Didymodon (Trichostomopsis) aaronis (Lorentz) J. Guerra, D. incrassatus (Lindb.) Broth., or D. haussknechtii (Jur. \& Milde) Broth., which were put into synonymy with $D$. australasiae by Jiménez et al. (2005).

Didymodon australasiae has repeatedly been assigned to the genus Trichostomopsis, together with the closely related D. umbrosus (Müll. Hal.) R.H. Zander. The inclusion of Trichostomopsis into the broadly conceived genus Didymodon is nevertheless supported by molecular data (Werner et al., 2005, Kučera \& Igna-

1 - V. L. Komarov Botanical Institute Rus. Acad. Sci., Prof. Popov Str., 2, St. Petersburg, 197376 Russia - Россия 197376 СанктПетербург, ул. Проф. Попова, 2, Ботанический институт им. В.Л. Комарова РАН; e-mails: irinamosses@yandex.ru \& stereodon@yandex.ru

2 - Faculty of Biology, Moscow State University, Moscow 119991 Russia - Россия 119991 Москва, Московский государственный университет, Биологический факультет, каф. геоботаники; e-mail: arctoa@list.ru

3 - University of South Bohemia, Faculty of Science, Department of Botany, Branišovsk 1760, CZ-370 05 České Budějovice, Czech Republic, e-mail: kucera@prf.jcu.cz 


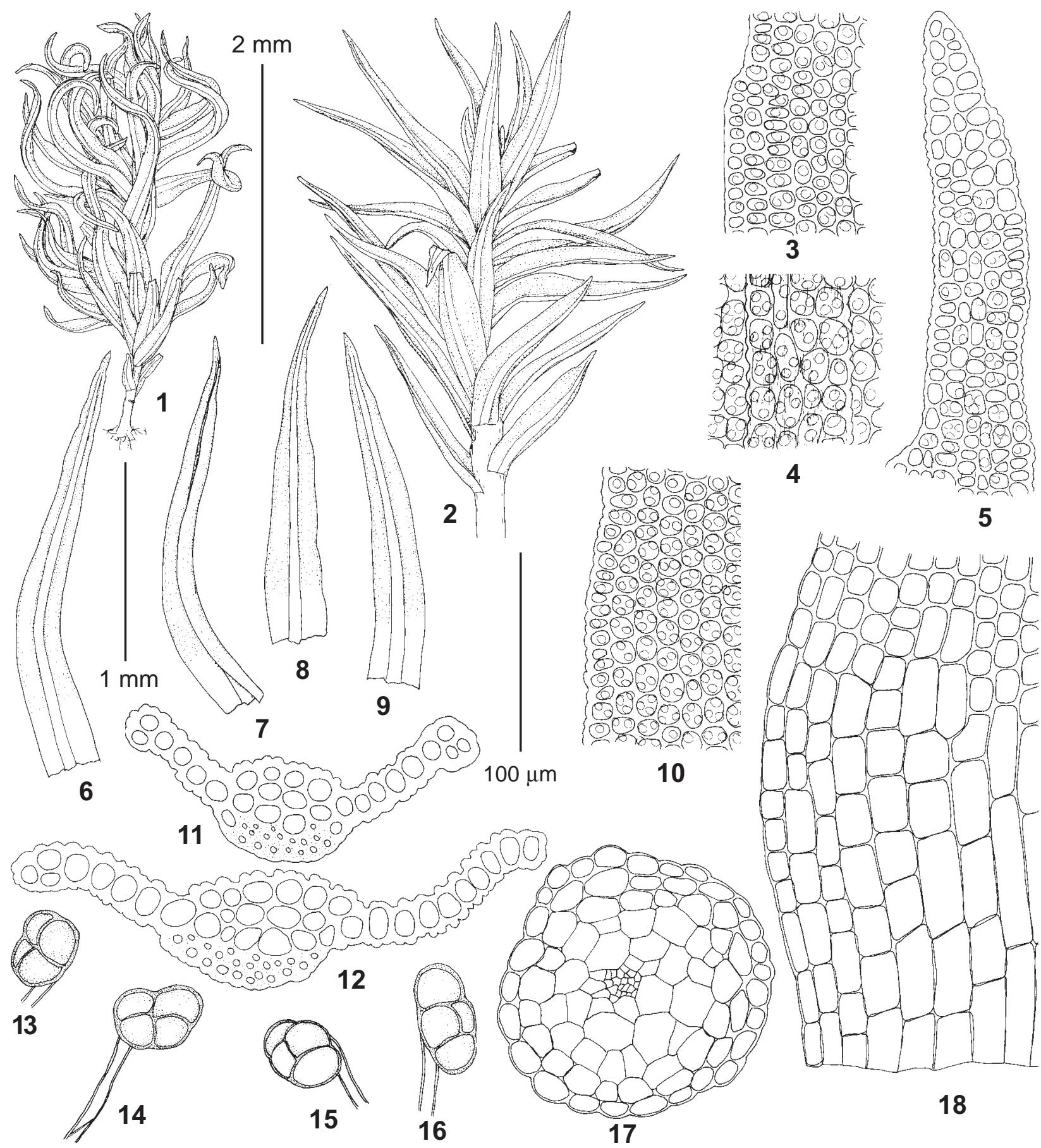

Fig. 1. Didymodon australasiae (Hook. \& Grev.) R.H. Zander (from: Russia, Zabaikalsky Territory, Afonina A1010, LE). 1 habit, dry; 2 - habit, wet; 3 - upper lamina cells; 4 - surface cells on adaxial side costa in mid-leaf; 5 - leaf tip; 6-9 - leaves; 10 - median lamina cells; 11-12 - leaf transverse secions; 13-16 - rhizoidal tubers; 17 - stem transverse section; 18 - basal lamina cells. Scale bars: $2 \mathrm{~mm}$ for $1-2 ; 1 \mathrm{~mm}$ for $6-9 ; 100 \mu \mathrm{m}$ for $3-5,10-18$.

tov, 2015), unless the genus is split into several smaller segregate genera, as suggested by Zander (2013).

TAXONOMIC TREATMENT

Didymodon australasiae (Hook. \& Grev.) R.H. Zander, Phytologia 41: 21. 1978.

Fig. 1

For the extensive synonymy, refer to Jiménez et al. (2005).
Description based on the Russian material: Plants small, in rather loose tufts, dark-green or blackish green. Stems $0.5-2 \mathrm{~cm}$, erect, without hyalodermis, with central strand. Leaves crisped, twisted or incurved when dry, erecto-patent to spreading when moist, lanceolate, not keeled, $1.0-1.9 \times 0.1-0.3 \mathrm{~mm}$; margins papillose-crenulate, plane, slightly incurved in the mid of the leaf, bi- to tristratose in the distal leaf portion; costa $45-70 \mu \mathrm{m}$ wide 
at leaf base, ending below apex, in transverse section with guide cells in 1-2 layers, without ventral stereids, with 1-3 layers of dorsal stereids, ventral epidermis usually bulging, papillose, dorsal epidermis not differentiated (surface cells of costa elongate and smooth or papillose on abaxial side); lamina unistratose except for margins; upper and median lamina cells rounded, subquadrate, shortly rectangular or transversely rectangular, not or slightly sinuous, 9-20 $\mu \mathrm{m}$ wide and 7-14 $\mu \mathrm{m}$ long, with 2-3 papillae per cell, generally thick-walled; basal cells rectangular, hyaline, smooth, thin-walled, $8-12 \mu \mathrm{m}$ wide and 14-40 $\mu \mathrm{m}$ long; marginal basal cells not or slightly differentiated. Rhizoidal tubers multicellular, irregularly shaped, with rounded-protuberant cells, 20-40 $\mu \mathrm{m}$ long, red-brown, smooth. Sporophytes not seen in Siberian specimens, their description follows Jiménez (2006). [Dioicous. Seta erect, $0.5-2 \mathrm{~cm}$, reddish brown to yellow. Capsule erect, cylindrical, urn $0.85-2 \times 0.4-0.8 \mathrm{~mm}$, brown to reddish brown. Peristome of 32 filiform teeth, papillose, straight or slightly twisted, $250-850 \mu \mathrm{m}$ long, occasionally rudimentary, yellowish brown. Operculum long rostrate, (0.45-)0.65-1.19 (-1.40) mm long. Calyptra $1.6-3 \mathrm{~mm}$ long. Spores $7.5-15 \mu \mathrm{m}$ in diameter, weakly papillose, yellowish green to brown].

Specimens examined: Russia: Zabaikalsky Territory: Kyra District, Sokhondinsky Biosphere Reserve: Enda River, $49^{\circ} 27^{\prime} \mathrm{N}, 110^{\circ} 50^{\prime} \mathrm{E}, 1220 \mathrm{~m}, 8$.VII.2010, Afonina A0810, A1010 (LE); Enda River, 49²6’N, 11048’E, 1473 m, 28.VII.2011, Czernyadjeva 55-11 (LE); Enda River, valley of Shanarichi

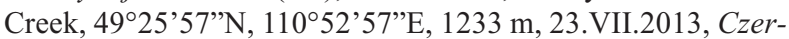
nyadjeva 48-13 (LE); Agutsa River, 4940’N, 111²6’E, 1098 m, 18.VII.2010, Afonina A3610 (LE).

Differentiation. Despite its variability, Didymodon australasiae can be recognized from its congeners by the combination of bi- to tristratose margins in upper half of leaf, transversal section of costa without ventral stereids, basal lamina cells elongate-rectangular and hyaline, and the regular presence of small irregular rhizoidal tubers. It is most similar to D. umbrosus, not yet detected in Russia, which differs in the presence of stem hyalodermis and differentiated narrow long-rectangular basal marginal cells in 2-6 rows. Another similar species, $D$. glaucus Ryan, differs in its mostly unistratose leaf margins and larger, nearly spherical gemmae, which are born on modified rhizoids in leaf axils and mostly are aboveground.

Ecology. In Sokhondinsky Reserve, the species was collected in a rather small quantity on a steppe slope in niches and cracks of south-facing rock outcrops and on soil among rocks. It formed small, loose tufts, sometimes with admixtures of Bryoerythrophyllum latinervium (Holmen) Fedosov \& Ignatova, Didymodon icmadophilus (Schimp. ex Müll. Hal.) K. Saito, Encalypta ciliata Hedw., and Mannia fragrans (Balb.) Frye \& L. Clark.

Distribution. Didymodon australasiae is distributed in mostly arid regions on all continents. It is known from the Mediterranean Region including Macaronesia, south- west and central Asia (Jordan, Israel, Lebanon, Turkey, Oman, Yemen, Iraq, Iran, Afganistan, Kazakhstan, Uzbekistan, Turkmenistan, Mongolia), northern and southern Africa (Morocco, Algeria, Tunisia, Egypt, Ethiopia, Cabo Verde, Zaire, Namibia, South Africa, Lesotho), North, Central and South America, Australia and New Zealand (Jiménez et al., 2005; O'Shea, 2006; Zander, 2007; Ros et al., 2013). The locality in Zabaikalsky Territory extends northwards its known distribution in Asia.

\section{ACKNOWLEDGMENTS}

The present study was carried out within the framework of the institutional research project (no. 123456) of Komarov Botanical Institute of the Russian Academy of Science and partly supported by RFBR 16-04-01156.

\section{LITERATURE CITED}

[ABRAMOV, I.I., A.L. ABRAMOVA \& I.V. SIROTINA] АБРАMOВ И.И., А.Л. АБРАМОВА, И.В. СИРОТИНА. 1986. Новые и интересные виды мхов из Туркмении. - [New and interesting mosses from the Turkmenistan] Новости систематики низших растений [Novosti Sistematiki Nizshikh Rastenij] 23: 197-204.

AFONINA, O. \& E. IGNATOVA. 2007 [2008]. A new species of Didymodon (Pottiaceae, Musci) from Asian Russia. - Arctoa 16: 133-138.

AFONINA, O.M., CZERNYADJEVA I.V., IGNATOVA E.A. \& J. KUČERA. 2010. Five species of Didymodon (Pottiaceae, Bryophyta) new for Russia. - Arctoa 19: 51-62.

IGNATOV, M.S., O.M. AFONINA, E.A. IGNATOVA et al. 2006 [2007]. Check-list of mosses of East Europe and North Asia. - Arctoa 15: 1-130.

JIMÉNEZ, J.A., R.M. ROS, M.J. CANO \& J. GUERRA. 2005. A new evalution of the genus Trichostomopsis (Pottiaceae, Bryophyta). - Botanical Journal of the Linnean Society 147(1): 117-127.

JIMÉNEZ, J.A. 2006. Taxonomic revision of the genus Didymodon Hedw. (Pottiaceae, Bryophyta) in Europe, north Africa and southwest and central Asia. - Journal of Hattori Botanical Laboratory 100: 211-292.

KUČERA, J. \& M.S. IGNATOV. 2015. Revision of phylogenetic relationships of Didymodon sect. Rufiduli (Pottiaceae, Musci). - Arctoa 24: 79-97.

O'SHEA, B. J. 2006. Checklist of the mosses of sub-Saharan Africa (version 5, 12/06). - Tropical Bryology Research Reports 6: 1-252.

ROS ESPÍN, R. M., V. MAZIMPAKA, U. ABOU-SALAMA, M. ALEFFI, T. L. BLOCKEEL, M. BRUGUÉS, R. M. CROS, M. G. DIA, G. M. DIRKSE, I. DRAPER, W. EL-SAADAWI, A. ERDAG, A. GANEVA, R. GABRIEL, J. M. GONZÁLEZ-MANCEBO, C. GRANGER, I. HERRNSTADT, V. HUGONNOT, K. KHALIL, H. KÜRSCHNER, A. LOSADA-LIMA, L. LUÍS, S. D. MIFSUD, M. PRIVITERA, M. PUGLISI, M. S. SABOVLJEVIĆ, C. SÉRGIO, H. M. SHABBARA, M. SIM-SIM, A. SOTIAUX, R. TACCHI, A. VANDERPOORTEN \& O. WERNER. 2013. Mosses of the Mediterranean, an annotated checklist. - Cryptogamie Bryologie 34: 99-283.

[TSEGMED, TS.] ЦЭГМЭД Ц. 2010. Флора мхов Монголии. - [Moss Flora of Mongolia] M. [Moscow], 634 pp.

WERNER, O., J. A.JIMÉNEZ, R. M. ROS, M. J. CANO \& J. GUERRA. 2005. Preliminary investigation of the systematics of Didymodon (Pottiaceae, Musci) based on nrITS sequence data. - Systematic Botany 30: $461-470$.

ZANDER, R.H. 1993. Genera of the Pottiaceae: mosses of harsh environments. - Bulletin of the Buffalo Society of Natural Sciences 32, vi + $378 \mathrm{pp}$.

ZANDER, R.H. 2007. Didymodon. - In: Flora of North America Editorial Committee (eds.). Flora of North America. 27. Bryophyta, part 1. Oxford University press, New York-Oxford: 539-561.

ZANDER, R.H. 2013. A framework for post-phylogenetic systematics. Zetetic Publications, St. Louis, MO, [iv] +209 pp. 